\title{
Policy Model of Sustainable Public Transport Accessibility in Sukabumi City of Indonesia
}

\author{
I Made Arka Hermawan * \\ $\mathrm{PhD}$ student of Natural Resources and Environmental Management Studi Program, Bogor Agricultural \\ University, Indonesia \\ Santun R.P Sitorus \\ Department of Soil Science and Land Resources, Faculty of Agriculture, Bogor Agricultural Institute, Indonesia \\ Machfud \\ Department of Agricultural Industry Technology, Faculty of Agricultural Technology, Bogor Agricultural \\ University, Indonesia \\ Umar Mansyur \\ Postgraduate Region of Planning Program in the Pakuan University, Bogor, Indonesia \\ I.F Poernomosidhi Poerwo \\ Research and Development Agency, Ministry of Public Works and Public Housing, Indonesia
}

\begin{abstract}
Sustainable development concept is something a matter to be carried by every country within which must be followed up by the underneath sectors such as sustainable transportation, especially concerning the public transport accessibility. Public transport accessibility problem is crucial to be solved in particular of urban areas like travel distance, cost, and time of someone who conducting the mobility. Research objectives are: (1) analyze the sustainability status of public transport accessibility by using sustainable transportation accessibility criteria and indicators; (2) formulate actions for public transport accessibility priority activities in Sukabumi City; (3) designing a public transport accessibility policy model with a dynamic system; (4) arrange the direction of policies to improve accessibility of sustainable public transport. Each criteria's indicator of public transport sustainability in Sukabumi City is determined by economic, social, environmental, institutional and legal approaches. Results of the sustainability index analysis show that for economic criteria, it is 47.96 , social criteria 23.58 , environmental criteria 82.95 , while institutional and legal criteria are 43.61 , so the average sustainability index is 49.61 and it can be said to be less sustainable. Activity programs to improve the accessibility of public transport in Sukabumi City, like in economic criteria is more directed at saving transportation costs, such as minimizing vehicle operating costs; social criteria is to increase public interest in switching to public transportation; environmental criteria is to fuel efficiency; and institutional and law criteria is more towards efforts to plan sustainable transportation programs. The dynamic model offers 4 scenarios of sustainable public transport accessibility policy models. The best scenario is implemented in 3 policies which consist of: optimization of vehicle operating costs, savings in fuel oil costs, and an increase in the number of people traveling with public transport. The results of this study are expected to be useful for stakeholders, especially the government as a reference in developing public transport sustainable city.
\end{abstract}

Keywords : accessibility, mobility, sustainable transportation, vehicle operating costs

DOI: $10.7176 / \mathrm{JESD} / 10-8-10$

Publication date: April $30^{\text {th }} 2019$

\section{Introductions}

The Central Statistics Agency (2015) stated that the population growth in Indonesia between 2000 and 2010 was $1.49 \%$ per year. Meanwhile the United Nations (UN) (2015) states that the population in Indonesia in 2015 amounted to more than 250 million people, more than 270 million in 2025 , more than 285 million in 2035 and 290 million in 2045. The high number of residents will certainly have an impact on the mobility of people on trips whether it is travel activities carried out routinely or that are not routine.

Of course population mobility must also be supported by good transportation accessibility. Accessibility is a measure of convenience or convenience regarding the way land use interacts with each other and easy or difficult locations are achieved through a transportation network system (Black and Conroy, 1977). Geurs and Wee (2004) state that transportation accessibility consists of 4 (four) components, namely: transport components (travel speed, travel time, and travel costs); land use component: number and distribution of people's trips; temporary component: travel time period; and individual components: stratification based on travel, income and education level.

According to The Central Statistics Agency, Sukabumi City (2018) Sukabumi City has a population in 2017 
of 335,866 people, with a growth rate of $1.5 \%$ per year. This is the same as the national population growth rate. Sukabumi City Transportation Agency (2015) stated that the condition of the people of Sukabumi City is currently served by 19 city transportation routes, with a capacity of 9 (nine) seats and 1,544 fleets. STTD street vendors (2015) stated that the operational characteristics of public transport in Sukabumi City, such as: the level of operation, frequency, headway, load factor, and speed showed a number below the Minimum Service Standard. The ratio of operating vehicles shows $75 \%$, load factor of $27 \%$, average travel speed of $26.11 \mathrm{~km} /$ hour. The current level of use of public transportation modes is $12 \%$ and the vehicle operating costs averaged Rp. 144,058, - per day or Rp. 57,839,480, - per year. The relatively low speed of public transport, the operation rate of the vehicle with a relatively small percentage, and the loading factor that shows a magnitude that is far from expectations, it is necessary to research the Public Transportation Accessibility Policy Model in Sukabumi City.

Research on transportation management, indicators of sustainable transportation, accessibility of public transport has been widely implemented. Some similar studies that have been carried out can be described as follows. Bayuaji (2004) conducted a research on the analysis of accessibility of regular public transport with instrument variables is the waiting time of public transport vehicles. The analysis used is an index of travel accessibility using public transportation. The results of this study are to determine the accessibility level of each zone with the development of public transport routes. Similar research related to public transport accessibility is Suthanaya (2009) by conducting research on transportation accessibility to the city center in Denpasar. The instrument variables used in addition to waiting time are walking time, and travel time. The analysis used is public transport accessibility index analysis, with accessibility index results in each traffic zone in the city of Denpasar. Lubis et al. (2012) researched generation modeling and transportation accessibility in residential areas. Some of the variables used as instruments were trip generation, the ease of carrying out transportation activities, the number of families, the last education of the head of the family, family income, car ownership, road conditions, and the ease of obtaining public transportation. The analysis used is trip generation analysis, while the resulting output is a trip generation model for residential areas.

Dangnga (2002) conducted a study of the interaction between the influence of the population and the environmental quality of facilities and infrastructure as well as environmental quality factors. The instrument variables used are: population growth, housing growth, and environmental quality. The analysis used is an analysis of the needs of facilities and infrastructure as well as factors that influence the quality of the environment. Kumalasari et al. (2011) examined the effect of land use on travel attraction, congestion costs and accident costs. Instrument variables are congestion costs, accident costs, and number of trips. The analysis used is a trip pull analysis with the results of the study in the form of travel pull models for congestion costs and accident costs.

Brotodewo (2010) and Judiantono (2012) examined several sustainable transportation indicators with economic, social, and environmental indicator variables. Herman's (2011) research is more on indicators of community participation with indicators of transport conditions (fuel, tariffs, public transport). Judiantono (2012) examines the analysis of transportation indicators associated with economic growth. The variables used by the three researchers are very diverse related to sustainability and the results released are also varied. The results of Brotodewo's study (2010) show an increase in regional accessibility, increased efficiency of transportation activities, increased transportation productivity, while Herman (2012) 's research results are a form of community participation in a sustainable transportation system, and Judiantono (2012) regarding land use policies same as transportation policy.

Mansyur (2008) examined the management model of sustainable transportation of non-bus passenger public transportation in Makassar City with sustainable transportation aspects, route performance, and transportation tariff instruments. The analysis used is the performance of public transportation, policy priority models, tariff rates. The results of the study show information in route selection, input in formulating transport policy, and input into the management and operations of the company. Murbaintoro (2009) examined the model of sustainable residential development with variables of economic growth, population growth, the level of affordability of the community with the results of research on urban development policy directions and the development of vertical residential needs. Sitorus (2010) examines the model of sustainable infrastructure development policy in supporting the development of agropolitan areas with variable population numbers, land use, and agricultural production with the results of infrastructure development policies to support the development of agropolitan areas. Hidajat (2014) examined the model of sustainable residential area management on the outskirts of Jabodetabek Metropolitan City by analyzing the management policy model. The output of this study is a policy model that is used as the basis for the preparation of strategic policy alternatives in residential area management.

Idris (2012) with a study entitled the management of sustainable transportation a future investment with variable use of fuel using an analysis of correlation between variables. The results of the study in the form of the concept of transportation development strategies in urban areas are aimed at the basis of the road, the public transportation base and the basis of traffic management, both transport management systems (TSM) and transport demand management (TDM) aspects. Andriani and Yuliastuti (2013) conducted a transportation system research that led to green transportation with a variable level of sustainability (economic, social, and environmental). The 
analysis used is a sustainable transportation index with outputs that are the compatibility between the sustainability index and the current transportation conditions. Kusbimanto et al. (2013) conducted a research on the Sustainability Analysis of Urban Transportation Infrastructure Development in Mamminasata Metropolitan South Sulawesi Province. The variables used are the level of sustainability of economic, social, and environmental aspects. The analysis using sustainability analysis and outputs is the sustainability status of the road network system and the key factors that influence the sustainability of transportation infrastructure development.

The results of some of the previous studies show that both of the variables used and the analysis and output methods, it can be concluded that until now no research has been carried out on the Model of Sustainable Public Transport Accessibility Policies in Sukabumi City. The methodology and substance that will be applied in this study are different from some previous studies.

\section{Methodology}

\subsection{Method of collecting data}

The method of data collection in this study was carried out through primary surveys and secondary surveys. The primary survey is conducted by an expert survey method used in conducting in-depth interviews (in-depth interviews) with samples that have been determined / deliberately chosen (purposive sampling). Marimin (2004) states that the expected data is the opinions of experts related to indicators of public transport accessibility and also an assessment of the sustainability index, both from economic, social, environmental, and institutional and legal criteria. In addition to these opinions, it is also expected to provide solutions in the form of action activities to assess each of these criteria.

Secondary data was obtained from public transport performance data obtained from the 2015 STTD PKL Team general report conducted in Sukabumi City. Some of the data obtained is related to the characteristics and performance of urban public transport in Sukabumi City, such as: fleet operation level, fleet frequency, travel time, transportation costs, vehicle operating costs, and vehicle crew income.

\subsection{Data analysis method}

The data analysis method used in this study is Multi Dimensional Scaling (MDS) analysis to analyze the level of sustainability of public transport accessibility in Sukabumi City by using economic, social, environmental and institutional and legal criteria. The software used in the analysis of the level of sustainability is using Rapfish software, (Kavanagh and Pitcher, 2004). Pairwise comparation analysis (PCA) analysis was used to formulate the actions of priority public transport accessibility activities in Sukabumi City. PCA analysis is one stage in the analytic hierarchy process (AHP) (Saaty, 1980).

\section{Results And Discussion}

\subsection{Determining the Status of Sustainability of Public Transport Accessibility}

MDS results using Rapfish that are assessed based on existing conditions show the sustainability index value is multi criteria for public transport accessibility in Sukabumi City at 49.61 or less sustainable. This multi-criteria sustainability index value is still below the index for sustainability, which is equal to 50 . This value is obtained from the assessment of 19 indicators from 4 (four) criteria. Social criteria have the lowest sustainability index value compared to other criteria.

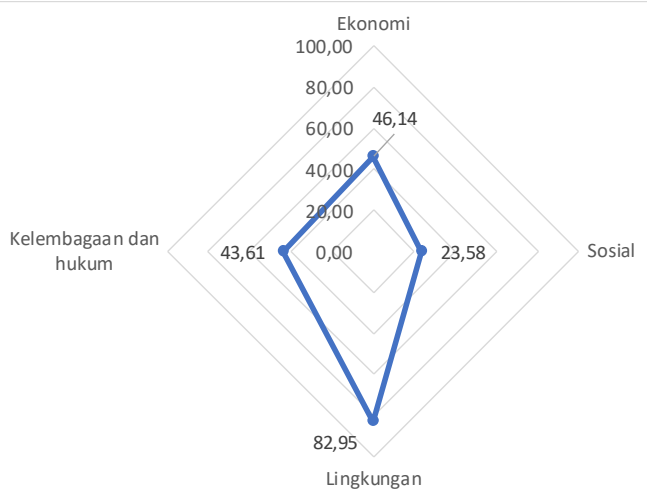

Figure 1 Kite diagram of the sustainability status of public transport accessibility in Sukabumi City

Monte Carlo analysis is used to see the error rate of MDS results with Rapfish at a 95\% confidence level. The results of the Monte Carlo analysis show that the sustainability index value of the MDS results is not much different from the index value of the Monte Carlo analysis. To find out the indicators studied in the MDS analysis is quite accurate and scientifically accountable, it can be seen from the value of stress and the value of the coefficient of determination $\left(\mathrm{R}^{2}\right)$ as the MDS output using the Rapfish software. The output of the analysis is considered quite 
accurate and can be accounted for if it has a stress value smaller than 0.25 or $25 \%$ and the coefficient of determination $\left(\mathrm{R}^{2}\right)$ approaches the value of 1.0 or 100 percent (Kavanagh and Pitcher 2004). The output of the analysis shows that all indicators analyzed are accurate and accountable. This can be seen from the stress value of $0.15-0.20$ and the Determination coefficient value $\left(\mathrm{R}^{2}\right) 0.93$ or $93 \%$.

As stated above, what influences the unsustainability of public transport accessibility is the social dimension and is the lowest index compared to other criteria. Indicators of the level of use of public transport, transport rates and the rate of traffic accidents are the lowest indicators. The poor quality of services currently available is one factor where people are reluctant to use public transport, in addition to relatively expensive tariffs and a low level of safety. The level of public transport use in Sukabumi City is currently 11\% (STTD PKL Team, 2015), while motorcycle use is $65 \%$. The high use of motorbikes is a result of poor public transport services and transport fares that are considered expensive. The impact of the magnitude of motorcycle usage is the high level of accidents. The Central Statistics Agency of Sukabumi City (2016), stated that in 2015 the number of accidents numbered 222 incidents with 51 dead, 23 seriously injured, 260 slightly injured, while material losses amounted to Rp. $431,070,000,-$. Frequency of events, number of victims, and material losses due to traffic accidents, 2015 was the largest year compared to the previous 5 (five) years.

Influential indicators are factors with root means square (RMS) values in the middle to the highest. From the results of the analysis of leverage factors obtained sensitive indicators or key indicators of the value of the sustainability index of each dimension are: economic dimensions there are 4 (four) indicators, there are 3 (three) indicators, environmental dimensions there are 2 (two) indicators, dimensions institutions and law there are 2 (two) indicators.

The economic dimension with influential indicators is the demand for travel by public transport, vehicle operating costs, and public transportation costs. The social dimension with influential indicators is the level of use of public transport, environmental dimensions with indicators of the level of energy use of public transport, and institutional and legal dimensions with indicators of sustainable transportation programs.

Indicators of travel demand by public transport and vehicle operating costs are indicators that need attention for accessibility of public transport with an increased economic dimension. The social dimension is the level of use of public transport and transport rates, the environmental dimension of the level of energy use of public transport, and the institutional dimension is a sustainable transportation program.

\subsection{Action on Sustainable Public Transport Accessibility Activities}

The actions of sustainable public transport accessibility activities are carried out using the Paired Comparison Analysis (Pairing Comparison Analysis). Each economic, social, environmental and institutional criterion is composed of sub-criteria, then each subcriteria is elaborated by several alternative action activities.

The economic dimension with interventions to increase the use of public transport is done by increasing the share mode or transferring people to public transport modes. Some of the activities carried out are evaluating the urban transport service network, maximizing the frequency of public transport, increasing the capacity of public transport, and increasing hours of public transport operations in Sukabumi City. Another intervention is to reduce transportation costs for the people of Sukabumi City. Some things that need to be done include: conducting traffic management and engineering by increasing the speed of traffic in accordance with urban road standards, reducing the operating costs of public transport vehicles, and operating public transport fleets with greater capacity.

The social dimension with the criteria of balancing public transport tariffs is by taking action to minimize the operating costs of public transport fleet vehicles, increasing public transport users by increasing the quality of public transport services as a minimum service standard.

The environmental dimension with the criteria of reducing the level of general transport energy use. One of the things that is done is by operating a fleet with greater capacity, so that there is energy savings used and reducing travel by private vehicles and switching to public transportation.

The institutional dimension with the criteria for planning a sustainable transportation program. One of the activities is to develop TOD (Transit Oriented Development) points in several mixed land uses in Sukabumi City. This is expected to reduce travel by private vehicles and increase the use of public transport and will also increase pedestrians and bicyclists.

\subsection{Dynamic Model of Sustainable Public Transport Accessibility Policy}

The sustainability index of public transport accessibility is a combination of each sustainability index in the dynamic sub-model which consists of a sustainability index of vehicle operating costs and public transport rates, a population sustainability index, and an index of the sustainability of the number of public transport users. The sustainability index for each sub-model, namely: sub-model of vehicle operating costs and public transport rates, sub-models of population numbers and sub-models of the number of public transport users have different units. The population increase index (person / year) has a negative tendency, meaning that with increasing years the population is expected to decrease. The number of users of public transport trips (people / days) has a positive 
tendency, it is expected that from year to year the users of public transportation will increase. Fleet requirements (units) have a declining trend, it is expected that with increasing years, the number of fleet needs will decrease. Users of BBM (liters of fuel) (liters / day) have a negative tendency, with increasing years, the trend of fuel use decreases, unless there are other scenarios such as: the increase in the number of rents or the increasing operation of the fleet. Fuel consumption $(\mathrm{Rp} . / \mathrm{Km})$ with a negative tendency, the increasing number of years is expected to decrease fuel consumption. Vehicle operating costs (Rp. / Year) with negative trends, increasing years are expected to decline, except for the operation of a larger fleet and changes in operational characteristics such as the addition of rites. Public transport tariffs $(\mathrm{Rp}$. / Km) have a negative tendency, the decreasing size of transport fares, the sustainability index of public transport accessibility is getting better. The combined flow chart of the four submodels of sustainable public transport accessibility can be seen in Figure 2.

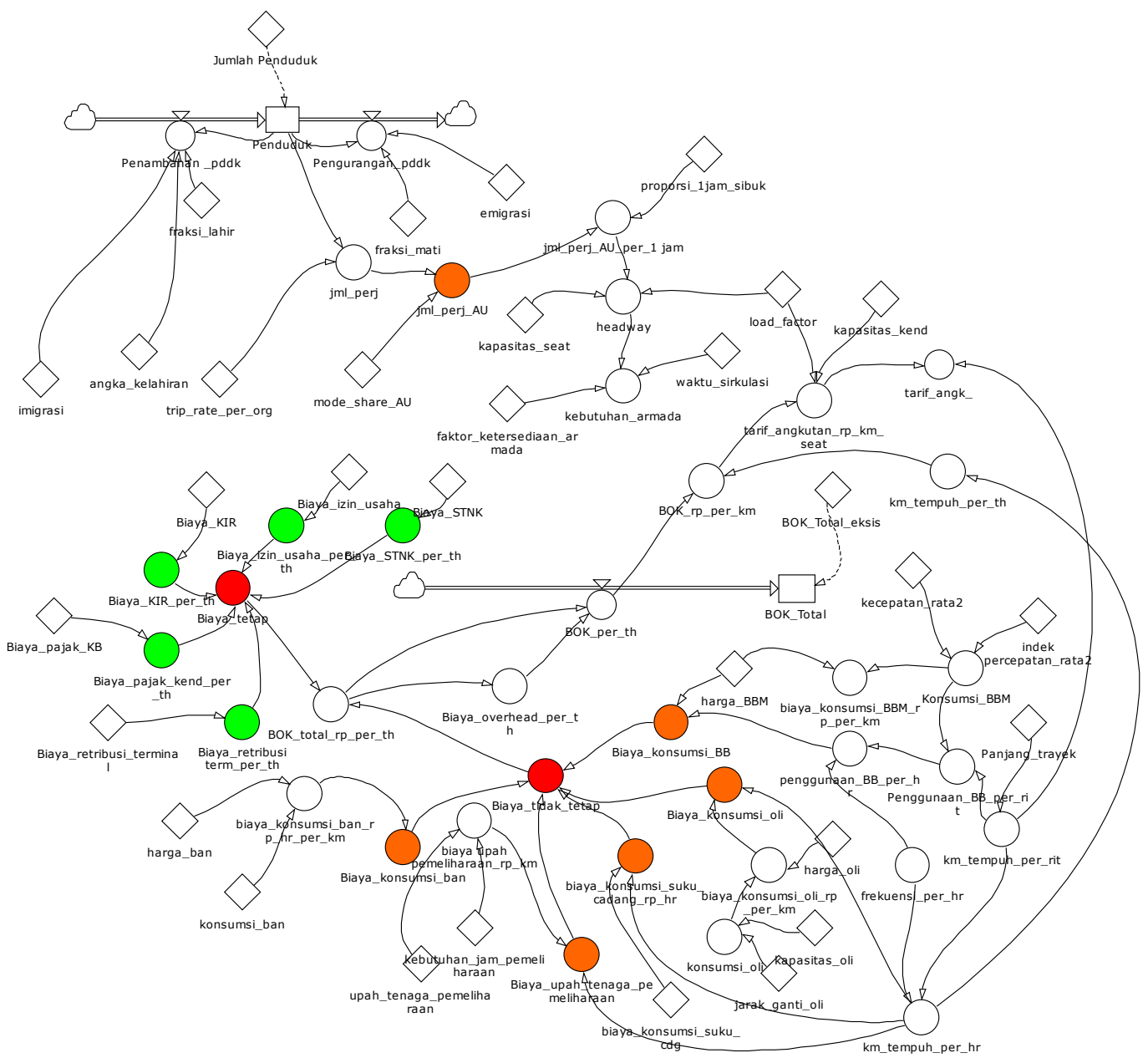

Figure 2 Flow chart of the sustainability index of public transport accessibility in Sukabumi City

Model testing is done by validity test by using the Mean Absolute Percentage Error (MAPE) statistical method. MAPE indicates how much error in forecasting is compared to real value. MAPE is carried out on elements of the population. The results of the validation test based on population indicate that MAPE deviates by 0.0098 from the actual data. This number is still within the deviation limit of less than $10 \%$. This shows that this model is able to simulate changes that occur in the actual field.

Scenario simulations of sustainable public transport accessibility policy models are carried out by intervening in several parameters from the social and economic dimensions, with several scenarios, as in Table 1. 
Table 1 Intervention scenario model parameters

\begin{tabular}{lrrrr}
\hline \multirow{2}{*}{ Parameters intervened } & \multicolumn{4}{c}{ Skenario } \\
\cline { 2 - 5 } Social & Do nothing & pessimist & moderate & optimistic \\
\hline a. The migration rate (\% per year) & & & & \\
\hline b. Mode share (\%) & 4,23 & 3,00 & 2,00 & 1,00 \\
\hline Economy & 12 & 20 & 28 & 32 \\
\hline a. Load factor (\%) & & & & \\
\hline b. capacity vehicles (seat) & 27 & 40 & 60 & 70 \\
\hline c. Speed traffic (km/h) & 12 & 12 & 15 & 25 \\
\hline d. Frequency vehicles (times / day) & 26 & 30 & 35 & 40 \\
\hline CPI outcome a & 6 & 8 & 10 & 12 \\
\hline
\end{tabular}

CPI outcome assessment of each sub-model can be seen in Table 2 where the lowest score for the sustainability index was 70.36 and the highest 104.94. If the value of the index was converted into 100, then the value of the lowest being 67.05. As a result of analysis of the sustainability of the accessibility of public transport in Mumbai by using Multidimensional Scaling (MDS), the index of sustainability, accessibility of public transport in Mumbai today is 49.07 or less sustainable. If the results of the model for the scenario without intervention (do nothing) is assumed to be the current state, then the value of sustainability index angkutuan general accessibility in Mumbai at 70.36 is less sustainable. Table 3 shows that the greater the value of the index rising status of sustainability, accessibility of public transport.

Table 2 Index of sustainability, accessibility of public transport model

\begin{tabular}{lcccrrrr}
\hline Scenario & $\begin{array}{c}\text { Addition of } \\
\text { population } \\
\text { (people/yr) }\end{array}$ & $\begin{array}{c}\text { Number of } \\
\text { public } \\
\text { transport } \\
\text { trips } \\
\text { (people) }\end{array}$ & $\begin{array}{c}\text { Fleet } \\
\text { needs } \\
\text { (units) }\end{array}$ & $\begin{array}{c}\text { Use of } \\
\text { fuel } \\
(\mathbf{I t r} / \mathbf{d a y})\end{array}$ & $\begin{array}{c}\text { Fuel } \\
\text { consumpt } \\
\text { ion } \\
\text { (Rp/km) }\end{array}$ & $\begin{array}{c}\text { Vehicle } \\
\text { operating } \\
\text { cost (Rp/yr) }\end{array}$ & $\begin{array}{c}\text { Public } \\
\text { transport } \\
\text { rates } \\
\text { (Rp/km) }\end{array}$ \\
\hline Do Nothing & 25.112 & 76.972 & 42 & 13 & 760 & 5.114 .855 & 450 \\
\hline Pessimist & 18.760 & 113.695 & 41 & 15 & 659 & 6.089 .539 & 270 \\
\hline Moderate & 14.482 & 144.825 & 28 & 16 & 565 & 6.965 .336 & 160 \\
\hline Optimistic & 10.860 & 151.095 & 15 & 16 & 494 & 7.813 .186 & 130 \\
\hline Trend & Negative & Positive & Negative & Negative & Negative & Negative & Negative \\
\hline
\end{tabular}

Table 3 Sustainability index of public transport accessibility with CPI

\begin{tabular}{lcccccccrr}
\hline Scenario & $\begin{array}{c}\text { Addition of } \\
\text { population } \\
\text { (people/yr) }\end{array}$ & $\begin{array}{c}\text { Number of } \\
\text { public } \\
\text { transport } \\
\text { trips } \\
\text { (people) }\end{array}$ & $\begin{array}{c}\text { Fleet } \\
\text { needs } \\
\text { (units) }\end{array}$ & $\begin{array}{c}\text { Use of } \\
\text { fuel } \\
\text { (ltr/day) }\end{array}$ & $\begin{array}{c}\text { Fuel } \\
\text { consump- } \\
\text { tion } \\
\text { (Rp/km) }\end{array}$ & $\begin{array}{c}\text { Vehicle } \\
\text { operating } \\
\text { cost } \\
\text { (Rp/yr) }\end{array}$ & $\begin{array}{c}\text { Public } \\
\text { transport } \\
\text { rates } \\
\text { (Rp/km) }\end{array}$ & $\begin{array}{c}\text { Total } \\
\text { index } \\
\text { value }\end{array}$ & $\begin{array}{c}\text { Convert- } \\
\text { ion } \\
\text { value }\end{array}$ \\
\hline Do Nothing & 43 & 76.972 & 42 & 13 & 760 & 5.114 .855 & 450 & 70.36 & 67.05 \\
\hline Pessimist & 58 & 113.695 & 41 & 15 & 659 & 6.089 .539 & 270 & 79.07 & 75.35 \\
\hline Moderate & 75 & 144.825 & 28 & 16 & 565 & 6.965 .336 & 160 & 93.20 & 88.81 \\
\hline Optimistic & 100 & 151.095 & 15 & 16 & 494 & 7.813 .186 & 130 & 104.94 & 100.00 \\
\hline Criteria weigh1 & 0.100 & 0.150 & 0.100 & 0.150 & 0.150 & 0.175 & 0.175 \\
\hline
\end{tabular}

Description: Weight is the result of AHP assessment

CPI: Composite Performance Index

The policy direction of the sustainable public transport accessibility model can be seen in Table 4 . 
Table 4 Model of sustainable infrastructure development policy

\begin{tabular}{|c|c|c|c|}
\hline Dimension & Kebijakan & Program & Rencana Tindak \\
\hline \multirow[t]{3}{*}{ Economy } & $\begin{array}{l}\text { Optimization of vehicle } \\
\text { operating costs }\end{array}$ & $\begin{array}{l}\text { Structuring the number } \\
\text { of fleets }\end{array}$ & $\begin{array}{l}\text { Rationalization } \quad \text { of } \\
\text { transportation }\end{array}$ \\
\hline & & $\begin{array}{ll}\text { Optimizing } & \text { public } \\
\text { transport tariffs } & \end{array}$ & Supervision of tariffs \\
\hline & $\begin{array}{l}\text { Optimization of vehicle } \\
\text { operating costs Increased } \\
\text { vehicle operating level }\end{array}$ & $\begin{array}{l}\text { Improved service } \\
\text { quality }\end{array}$ & $\begin{array}{l}\text { Addition of frequency of } \\
\text { transportation services }\end{array}$ \\
\hline \multirow[t]{4}{*}{ Social } & $\begin{array}{l}\text { Control of population } \\
\text { growth }\end{array}$ & $\begin{array}{l}\text { Restrictions on } \\
\text { residents who will enter } \\
\text { Sukabumi City }\end{array}$ & $\begin{array}{l}\text { Control of population through legal } \\
\text { operations and development of } \\
\text { business centers in suburban areas }\end{array}$ \\
\hline & $\begin{array}{l}\text { Increased number of people } \\
\text { using public transportation }\end{array}$ & $\begin{array}{l}\text { Development of mass } \\
\text { transportation }\end{array}$ & $\begin{array}{l}\text { Application of Miminal Service } \\
\text { Standards for urban public transport }\end{array}$ \\
\hline & & $\begin{array}{l}\text { Integration of transport } \\
\text { services }\end{array}$ & $\begin{array}{l}\text { Connectivity types of public } \\
\text { transport services }\end{array}$ \\
\hline & $\begin{array}{l}\text { Increased feasibility of } \\
\text { public transport services }\end{array}$ & $\begin{array}{l}\text { Improving the quality of } \\
\text { public transport services }\end{array}$ & $\begin{array}{l}\text { Application of Minimum } \\
\begin{array}{l}\text { Standards forvice } \\
\text { transportation }\end{array}\end{array}$ \\
\hline \multirow[t]{3}{*}{ Environment } & $\begin{array}{l}\text { Development of mass public } \\
\text { transportation }\end{array}$ & Blue sky program & $\begin{array}{l}\text { Supervision of motorized vehicle } \\
\text { testing (public transportation) }\end{array}$ \\
\hline & $\begin{array}{l}\text { Traffic management and } \\
\text { engineering }\end{array}$ & $\begin{array}{ll}\text { Reduced } & \text { traffic } \\
\text { congestion } & \\
\end{array}$ & General transport priority \\
\hline & $\begin{array}{l}\text { Reduction of public } \\
\text { transport energy use }\end{array}$ & Vehicle restrictions & Application of renewable fuel energy \\
\hline \multirow[t]{3}{*}{ Institutional } & $\begin{array}{l}\text { Promote sustainable } \\
\text { transportation programs }\end{array}$ & $\begin{array}{l}\text { Reliable public } \\
\text { transport planning }\end{array}$ & Integrated public transport planning \\
\hline & Public transport budgeting & $\begin{array}{l}\text { Increased budget for } \\
\text { sustainable } \\
\text { transportation }\end{array}$ & $\begin{array}{l}\text { Public transportation funding } \\
\text { between the government and the } \\
\text { private sector }\end{array}$ \\
\hline & Law enforcement & $\begin{array}{l}\text { Public transport policy } \\
\text { interventions }\end{array}$ & $\begin{array}{l}\text { Policy or legalization that supports } \\
\text { law enforcement }\end{array}$ \\
\hline
\end{tabular}

\section{Conclusion}

Based on the results of the study it can be concluded the following matters:

a. The current status of accessibility of public transport in Sukabumi City is not sustainable with a multicriteria index value of 49.61, which means that accessibility of public transport is still in a poor condition, so it needs to be improved to realize sustainable public transport accessibility.

b. There are 19 indicators of 4 (four) dimensions. The social dimension has the lowest sustainability index value compared to other dimensions. 19 of these priority indicators form the basis for developing a sustainable public transport accessibility policy model in Sukabumi City.

c. The dynamic model of sustainable public transport accessibility in the research area consisting of 2 (two) submodels, namely: the economic sub-model and the social sub-model have resulted in the formulation of the sustainability index value of public transport accessibility. The index value can be increased in line with scenario simulations. The results of the scenario without intervention and pessimism show a trend that is not sustainable with a relatively low level of sustainability. The results of moderate and optimistic scenarios have shown a level of sustainability that is better or already sustainable and very sustainable.

d. In order to increase the value of the sustainability status of public transport accessibility and so that the chosen scenario is implemented, it is necessary to support the right policies. The findings in the form of priority policies can be used as a basis to intervene in improving the sustainability status of public transport accessibility in the future. In order for this policy to be implemented, it is necessary to complete the program and action plan. 
References

Andriani DM dan Yuliastuti N, 2013, Penilaian Sistem Transportasi yang Mengarah pada Green Transportasi di Kota Surakarta, Jurnal Perencanaan Wilayah dan Kota 9 (2): 183-193.

Bayuaji A, 2014, Analisis Tingkat Aksesibilitas dengan Angkutan Umum Reguler di Kota Semarang [tesis], Semarang (ID): Universitas Diponegoro.

Black J and Conroy M, 1977, Accessibility measures and the social evaluation of urban structure. Environment and Planning A 9: 1013-1031.

Brotodewo N, 2010, Penilaian Indikator Transportasi Berkelanjutan Pada Kawasan Metropolitan di Indonesia, Jurnal Perencanaan Wilayah dan Kota 21 (3): 165-182.

Dangnga MS, 2002. Pengaruh Interaksi antara Pertumbuhan Penduduk, Permukiman dan Kualitas Lingkungan terhadap Saran dan Prasarana Permukiman dan Faktor-faktor Kualitas Lingkungan di Kota Makassar, Sulawesi Selatan [disertasi], Bogor (ID): Program Pascasarjana IPB.

Hidajat, T.J. 2014. Model Pengelolaan Kawasan Permukiman Berkelanjutan di Pinggiran Kota Metropolitan Jabodetabek [disertasi]. Bogor (ID): Program Pascasarjana IPB.

Idris Z.H. 2012. Pengelolaan Transportasi Berkelanjutan Sebuah Investasi Masa Depan, Seminar Nasional Teknik Sipil UMS: 112-117.

Judiantono and Tonny. 2012. Analisis Indikator Transportasi Jalan Raya dan Pertumbuhan Ekonomi di Provinsi Jawa Barat, Jurnal Perencanaan Wilayah dan Kota Unisba 6 (1): 1-11.

Kavanagh P and Pitcher T.J. 2004. Implementing Microsoft Excel Software for Rapfish: Atechnique for The Rapid Appraisal of Fisheries Status. (The Fisheries Centre 12 (2)), Canada: University of British Columbia.

Kumalasari D, Soemarno, dan Wicaksono A, 2011, Pengaruh Guna Lahan Terhadap Tarikan Pergerakan, Biaya Kemacetan dan Biaya Kecelakaan (di Jalan KH, Abdul Fatah - Jalan Kapten Kasihin Tulungagung), Jurnal Rekayasa Sipil, Universitas Brawijaya 5 (3): 168-179.

Kusbimanto W, Sitorus S.R.P. Machfud dan Poerwo I.F.P. 2013, Analisis Keberlanjutan Pengembangan Prasarana Transportasi Perkotaan di Metropolitan Mamminasata Provinsi Sulawesi Selatan, Jurnal Jalan dan Jembatan 30 (1): 1-15.

Lubis Z dan Bakhtiyar A. 2012. Pemodelan Bangkitan dan Aksesibilitas Transportasi di Kawasan Perumnas Made Lamongan. Jurnal Teknika 2 (2): 25-30. Universitas Islam Lamongan.

Mansyur U. 2008. Model Pengelolaan Transportasi Angkutan Umum Penumpang Non-Bus Berkelanjutan Kota Makassar [disertasi]. Bogor (ID): Program Pascasarjana IPB.

Marimin. 2004. Teknik dan Aplikasi: Pengambilan Keputusan Kriteria Majemuk. Jakarta (ID): Grasindo.

Murbaintoro T. 2009. Model Pengembangan Hunian Vertikal Menuju Pembangunan Perumahan Berkelanjutan, Jurnal Permukiman 4 (2): 72-87.

Ryan A, Dewi H dan Djumari. 2015. Analisis Kebutuhan Armada dan Jadwal Operasional Kampus dalam Rangka Mendukung Program Green Campus Bus. e-Jurnal Matriks Teknik Sipil 30 (1): 268-276.

Saaty T.L. 1980. The Analytic Hierarchy Process: Planning, Priority Setting, Resource Allocation, McGraw-Hill.

Sitorus S. 2010. Model Kebijakan Pembangunan Infrastruktur Berkelanjutan dalam Mendukung Pengembangan Kawasan Agropolitan (Studi Kasus di Kawasan Agropolitan Merapi-Merbabu) [disertasi]. Bogor (ID): Program Pascasarjana IPB.

Suthanaya P.A. 2009. Analisis Aksesibilitas Penumpang Angkutan Umum Menuju Pusat Kota Denpasar di Provinsi Bali. GaneÇ Swara Edisi Khusus 3 (3): 87-93.

[Tim PKL STTD]. Tim Praktek Kerja Lapangan Sekolah Tinggi Transportasi Darat. 2015. Laporan Umum Praktek Kerja Lapangan Kota Sukabumi. Bekasi (ID): STTD.

The Central Statistics Agency. 2015. Penduduk Indonesia menurut Provinsi 1971, 1980, 1990, 1995, 2000 dan 2010, Dapat diunduh dari https://www,bps,go,id/linkTabelStatis/view/id/1267.

The Central Statistics Agency Sukabumi City. 2018, Kota Sukabumi Dalam Angka 2018, Sukabumi (ID): Badan Pusat Statistik Kota Sukabumi. 